\title{
Abundance and Productivity of Marbled Murrelets (Brachyramphus marmoratus) Off Central California during the 2017 Breeding Season
}

Data Series 1093

U.S. Department of the Interior

U.S. Geological Survey 
Cover: Juvenile marbled murrelet (Brachyramphus marmoratus) off Santa Cruz, California. Photograph by David Presksta, Bureau of Ocean Energy Management, August 1, 2017. 


\section{Abundance and Productivity of Marbled Murrelets (Brachyramphus marmoratus) Off Central California during the 2017 Breeding Season}

By Jonathan J. Felis, Josh Adams, and Emily C. Kelsey

Data Series 1093 


\title{
U.S. Department of the Interior \\ RYAN K. ZINKE, Secretary
}

\author{
U.S. Geological Survey \\ James F. Reilly II, Director
}

U.S. Geological Survey, Reston, Virginia: 2018

For more information on the USGS — the Federal source for science about the Earth, its natural and living resources, natural hazards, and the environment-visit https://www.usgs.gov or call 1-888-ASK-USGS.

For an overview of USGS information products, including maps, imagery, and publications, visit https://store.usgs.gov.

Any use of trade, firm, or product names is for descriptive purposes only and does not imply endorsement by the U.S. Government.

Although this information product, for the most part, is in the public domain, it also may contain copyrighted materials as noted in the text. Permission to reproduce copyrighted items must be secured from the copyright owner.

Suggested citation:

Felis, J.J., Adams, J., and Kelsey, E.C.., 2018, Abundance and productivity of marbled murrelets (Brachyramphus marmoratus) off central California during the 2017 breeding season: U.S. Geological Survey Data Series 1093, 12 p., https://doi.org/10.3133/ds1093.

ISSN 2327-638X (online) 


\section{Contents}

Abstract
Introduction
Methods
At-Sea Survey Methods
Abundance Estimation Methods
Juvenile Ratio Estimation Methods
Abundance Estimation Results
Piscussion
Summary.
Acknowledgments
References Cited

\section{Figures}

1. Map of Conservation Zone 6 showing survey routes and marbled murrelet (Brachyramphus marmoratus) detections from Half Moon Bay to Santa Cruz, central California, 2017

2. Graph showing modeled detection probability of marbled murrelets (Brachyramphus marmoratus) sighted within perpendicular distance less than or equal to 120 meters of vessel for all surveys, Conservation Zone 6, central California, 2017

3. Graph showing mean annual marbled murrelets (Brachyramphus marmoratus) at-sea abundance estimates, Conservation Zone 6, central California, for all years for which survey data were available during 2001-17.

4. Graph showing date-corrected marbled murrelets (Brachyramphus marmoratus) hatch-year to after-hatch-year ratios, plus or minus standard errors, Conservation Zone 6, central California, for all years for which survey data was available during 1996-2017

\section{Tables}

1. Observer view condition classifications and descriptions for marbled murrelets (Brachyramphus marmoratus) surveys.

2. Marbled murrelett (Brachyramphus marmoratus) survey dates, route direction, effort, observations, and density/abundance estimates for all surveys,

Conservation Zone 6, central California, 2017

3. Annual at-sea marbled murrelets (Brachyramphus marmoratus) estimates for surveys drawn in both directions, surveys only drawn from the north, and surveys only drawn from the south, Conservation Zone 6, central California, 1999-2017

4. Annual estimates of hatch-year to after-hatch-year ratios, date-corrected ratios, and standard errors for marbled murrelets (Brachyramphus marmoratus) from at-sea surveys done during the breeding season, Conservation Zone 6, central California, 1996-2003 and 2007-17 


\section{Conversion Factors}

International System of Units to U.S. customary units

\begin{tabular}{|c|c|c|}
\hline Multiply & By & To obtain \\
\hline \multicolumn{3}{|c|}{ Length } \\
\hline meter (m) & 3.281 & foot (ft) \\
\hline meter (m) & 1.094 & yard (yd) \\
\hline kilometer $(\mathrm{km})$ & 0.6214 & mile (mi) \\
\hline
\end{tabular}

\section{Datum}

Horizontal coordinate information is referenced to the World Geodetic System of 1984 (WGS 84). 


\title{
Abundance and Productivity of Marbled Murrelets (Brachyramphus marmoratus) Off Central California during the 2017 Breeding Season
}

\author{
By Jonathan J. Felis, Josh Adams, and Emily C. Kelsey
}

\section{Abstract}

Marbled murrelets (Brachyramphus marmoratus) have been listed as "Endangered" by the State of California and "Threatened" by the U.S. Fish and Wildlife Service since 1992 in California, Oregon, and Washington. Information regarding marbled murrelet abundance, distribution, population trends, and habitat associations is critical for risk assessment, effective management and evaluation of conservation efficacy, and ultimately to meet Federal- and State-mandated recovery efforts for this species. During June-August 2017, the U.S. Geological Survey Western Ecological Research Center continued previously established, long-term (1999-2016), at-sea surveys to estimate abundance and productivity of marbled murrelets in U.S. Fish and Wildlife Service Conservation Zone 6 (central California-San Francisco Bay to Monterey Bay). Using conventional distance sampling methods, we estimated marbled murrelet abundance using 189 detections of 321 individuals observed on nine unique surveys. The abundance estimated for the entire study area using all surveys in 2017 was 530 birds (95-percent confidence interval, 384-732 birds). Estimated abundance from 2017 is comparable to most prior years of study, except for 2008 and 2015, which had anomalously low abundances. We estimated productivity (calculated as the hatch-year [HY] to after-hatchyear [AHY] ratio) in 2017 using three detections of three individuals observed in six surveys. After date-correcting HY and AHY counts to account for birds expected to be absent from the water while inland at nests, the date-corrected juvenile ratio was $0.022 \pm 0.014$ standard error. We created a synthesized database of all marbled murrelet survey data from 1999 to 2017 to allow scientists and managers to evaluate established survey methods and assess trends in abundance and productivity estimates. Future modifications of survey design could help reduce variance in abundance estimation.

\section{Introduction}

The marbled murrelet (Brachyramphus marmoratus) is a small, compact wing-propelled, diving seabird of the family Alcidae. Marbled murrelets inhabit North American nearshore marine waters from Alaska to central California. In California, marbled murrelets nest from April to August in forests within $80 \mathrm{~km}$ of the coast. The southernmost known breeding area for marbled murrelets occurs south of San Francisco in forested areas of the Santa Cruz Mountains near Point Año Nuevo, California, and is separated from the nearest northern California population by 240-320 km. An estimated 174-699 individuals comprise the annual breeding population of marbled murrelets in this disjunct area (Henry, 2017). During their breeding season of April to August, the distribution of marbled murrelets extends from Half Moon Bay to Santa Cruz, and is centered near Point Año Nuevo, San Mateo County (Henry, 2017). Sightings of marbled murrelets south of Santa Cruz in Monterey Bay during the breeding season are infrequent (Ralph and Miller, 1995; Henkel, 2004).

In 2017, the U.S. Geological Survey Western Ecological Research Center (USGS-WERC) partnered with California State Parks to continue long-term, at-sea surveys to estimate abundance and juvenile (that is, hatch-year) productivity of marbled murrelets in U.S. Fish and Wildlife Service Conservation Zone 6 (central California-San Francisco Bay to Monterey Bay). Marbled murrelets have been listed as "Endangered" by the State of California and "Threatened" by the U.S. Fish and Wildlife Service since 1992 in California, Oregon, and Washington. Abundance of marbled murrelets has been estimated at sea off central California since 1999 (excluding 2004-06; Henkel and Peery, 2008; Peery and others, 2009; Peery and Henry, 2010; Henry and others, 2012; Henry, 2017) and is funded by the U.S. Fish and Wildlife Service Natural Resource Damage Assessment and 
Restoration Program under the guidance of the Luckenbach Oil Spill Trustee Council. Information regarding marbled murrelet abundance, distribution, population trends, and habitat associations is critical for risk assessment, effective management and evaluation of conservation efficacy, and ultimately to meet Federal- and State-mandated recovery efforts for this species.

USGS-WERC continued at-sea surveys in 2017 to assess abundance and productivity for two primary purposes: (1) to maintain efforts to quantify the status of marbled murrelets in central California (FWS Conservation Zone 6), and (2) to help evaluate potential benefits and marbled murrelet response to ongoing corvid control in coastal California State parks. Additionally, marbled murrelet distribution data at sea may help resource managers designate critical at-sea habitat for the species. In this report, we describe our methods, and provide summaries of survey effort/routes and results estimating marbled murrelet abundance and productivity (juvenile ratio) for 2017.

\section{Methods}

\section{At-Sea Survey Methods}

In 2017, USGS-WERC completed nine at-sea surveys for marbled murrelets between Half Moon Bay and Santa Cruz, California (fig. 1). We conducted surveys during the previously established survey window (June 1-August 24; Henry, 2017) and allocated surveys to two periods within this window-three surveys during June 1-July 10 and six surveys during July 11-August 24. Surveys were almost exclusively conducted when viewing conditions were excellent to good (table 1). We used data from all surveys to estimate marbled murrelet abundance; however, we only used the six surveys during the second survey period to estimate juvenile ratio (following Henry, 2017).

Table 1. Observer view condition classifications and descriptions for marbled murrelet (Brachyramphus marmoratus) surveys.

\begin{tabular}{ll}
\hline \multicolumn{1}{c}{ View condition } & \multicolumn{1}{c}{ Description } \\
\hline 5- Excellent & Glassy \\
$\begin{array}{l}\text { - Very Good } \\
\text { - Good }\end{array}$ & $\begin{array}{l}\text { Wavelets and (or) minor glare } \\
\text { able to reliably detect murrelets within about } \\
150 \text { meters of line }\end{array}$ \\
& $\begin{array}{l}\text { Waves and/or moderate glare; chance of missing } \\
\text { - Fair }\end{array}$ \\
& $\begin{array}{c}\text { High wind wavelets within about 150 meters of line } \\
\text { - Poor }\end{array}$ \\
\end{tabular}

Historically, survey routes were designed as continuous, about 100-km zigzag transect lines to sample nearshore (200-1,350 m from coast) and offshore (1,350-2,500 m from coast) strata, with approximately four times greater effort within the nearshore stratum owing to greater marbled murrelet densities known to occur nearshore (see Henry, 2017, and references therein). Routes originally were drawn starting at a random distance (200-2,500 m) from shore, and an equal number of routes were drawn using starting points at the north and south ends of the survey area. Survey routes drawn from the south resulted in a greater amount of habitat surveyed in south-facing, leeward bays that often had greater relative abundances of marbled murrelets than more exposed stretches of the coast (Henry, 2017).

In 2017, we identified 10 unique survey routes (5 each drawn from north and south) used by Henry (2017) during 2013-16 surveys and randomly selected our survey routes from this pool (without replacement) for each survey; ultimately, we used 8 survey routes (4 drawn from the north and 4 from the south) to complete 9 surveys (one route was unintentionally surveyed twice). We conducted all surveys by following the selected route from north (Pillar Point Harbor, Half Moon Bay) to south (Soquel Point, Monterey Bay) using a Global Positioning System (GPS). When the survey route intersected land or crossed hazardous areas (for example, the extreme nearshore or passage between Año Nuevo Island and the mainland), we maintained survey effort while safely navigating to the next transect segment. We conducted surveys from a small boat using line-transect methods (Becker and others, 1997; Peery and others, 2006; Henry, 2017). Two observers, standing on either side of a 6-m open skiff ( $R / V$ Lucy $M$, also used during 2013-16) traveling 12-15 knots, recorded the observation time, angle off the transect line, and the distance to all groups of marbled murrelets detected. Observers counted marbled murrelets as a group when individuals were within $2 \mathrm{~m}$ of each other, or if they showed behavior indicative of group status (for example, co-diving or vocalizing with one another; Strong and others, 1995). Observers recorded the age-class of each marbled murrelet based on three plumage classifications: (1) "after-hatch-year" (AHY), (2) "hatch-year" (HY), or (3) "unknown." Behavior was recorded as "resting" on the water or "flying," with flight direction noted. Prior to each survey, observers calibrated distance estimation using a laser rangefinder on buoys in the harbor. To facilitate estimations of sighting angles, we placed marks along the bow of the boat in 10-degree increments. The vessel occasionally paused or deviated from the transect line to properly identify marbled murrelet age-class; no additional observations were counted during these deviations. 


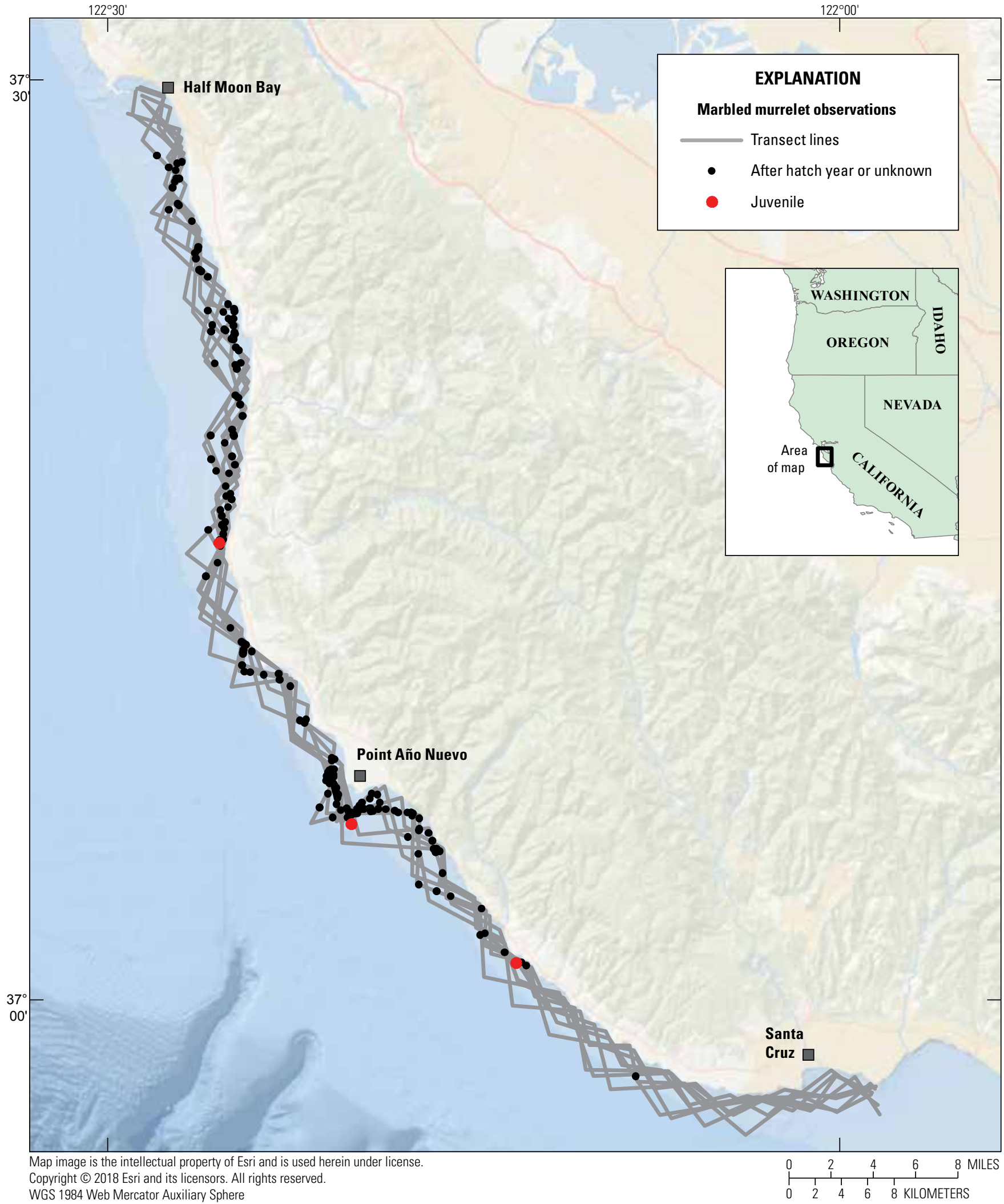

Figure 1. Conservation Zone 6 showing survey routes and marbled murrelet (Brachyramphus marmoratus) detections from Half Moon Bay to Santa Cruz, central California, 2017. 
Observers recorded all observations and observation times in digital voice recorders, including survey start and end times, ocean conditions (Beaufort Sea state), viewing conditions (table 1), and time periods when effort was paused for any reason (for example, vessel paused or deviated from the transect line to identify marbled murrelets age-class). Observers reviewed their own recordings and transcribed and tabulated their sighting data into a single spreadsheet that was examined for quality assurance and quality control and merged into a combined spreadsheet. We acquired a continuous 1-second GPS track during each survey using a handheld GPS unit; this track was used to geo-reference observations based on matching date/time using custom scripting in $\mathrm{R}$ (R Core Team, 2016). We created a spatial representation of strata in ArcGIS ${ }^{\mathrm{TM}}$ based on the same coastline shapefile used in previous years (California Department of Fish and Wildlife, 2004), and calculated linear effort for each survey in each stratum consistent with previous years by using the hypothetical survey route delineated by the zigzag segment nodes. During the first survey (USGS07S), no data were collected by one observer (that is, one side of the boat) during two short segments near the beginning of the transect line. Therefore, we accounted for this by reducing linear effort in each stratum according to the proportion of distance surveyed by only one observer. This resulted in 13 and 11 percent reductions in linear effort within the nearshore and offshore strata, respectively, on survey USGS07S (table 2).

\section{Abundance Estimation Methods}

We calculated perpendicular distance for each detection (sine of the sighting angle $\times$ observation distance) and inspected the distribution of perpendicular detection distances to select a truncation distance where detections approached zero, beyond which we excluded observations from analysis. Consistent with previous years, we included sightings of flying birds in our analysis, despite the potential that flying birds likely have a different probability of detection and including these could affect abundance estimates.

Table 2. Marbled murrelet (Brachyramphus marmoratus) survey dates, route direction, effort, observations, and density/abundance estimates for all surveys, Conservation Zone 6, central California, 2017.

[Route direction: Direction from which the route was drawn; all routes were surveyed from north to south. Abbreviations: $\mathrm{km}$, kilometer; $\mathrm{km}^{2}$, square kilometer; 95\% CI, 95-percent confidence interval of the abundance estimate]

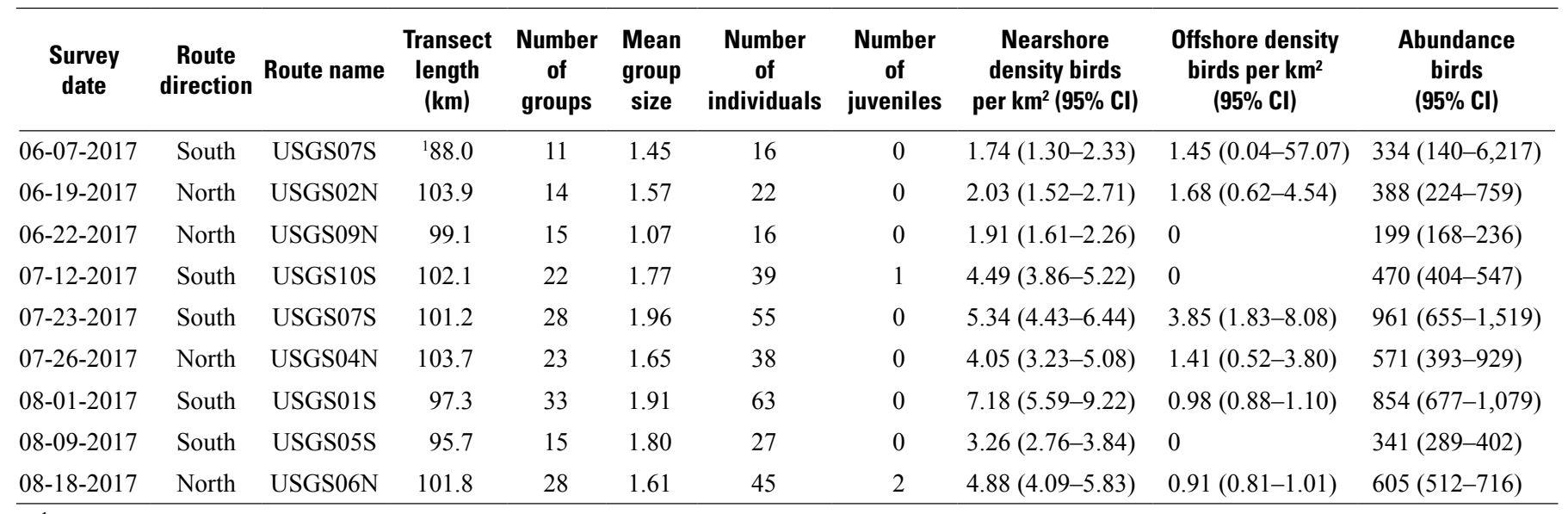

\footnotetext{
${ }^{1}$ Linear effort reduced to indicate lesser effort of one of the two observers on this survey (see section, "Methods" in text).
} 
Following Henry (2017), we used the program DISTANCE v7.1 (Thomas and others, 2010) to model our detection function and estimate murrelet abundance using conventional distance sampling (see Buckland and others, 2015, for a detailed description of methods for modeling and selecting detection functions and estimating abundance from line transects). Specifically, using DISTANCE v7.1, we pooled observations from all 2017 surveys to create a global detection function for 2017 surveys and applied this function to each survey to calculate stratum- and surveyspecific density estimates based on the linear effort sampled during each survey. Consistent with Henry (2017), we grouped perpendicular detection distances into 20 -m bins, used a 120 -m truncation distance, and evaluated the half-normal function, with or without cosine expansion; we selected the detection function with the smallest Akaike information criterion (AIC; Burnham and Anderson, 2004) value (that is, most parsimonious fit). We used the mean of observed cluster size method to estimate cluster (group) sizes. We assigned marbled murrelet observations to either the nearshore or offshore stratum in ArcGIS ${ }^{\mathrm{TM}}$ based on spatial overlap. We calculated survey-specific abundances by multiplying the stratum-specific density estimate by the total area of each stratum in the study area (104.65 $\mathrm{km}^{2}$ for each) and then summed the two stratum-specific abundance values for a total area abundance estimate. Consistent with Henry (2017), we repeated the analysis described above with the data partitioned by survey route draw direction to evaluate the effect of survey route direction on abundance estimation. New, direction-specific detection functions were modeled for these subsets of the data and used to estimate abundance (following Henry, 2017). We report annual abundances and 95-percent confidence intervals (95-percent CI) estimated by DISTANCE v7.1.

\section{Juvenile Ratio Estimation Methods}

We estimated the juvenile ratio (the ratio of HY to AHY individuals) for marbled murrelet surveys conducted during the fledging period. The fledging period ranged from July 10, when an estimated 34-percent of HY birds were estimated to have fledged, to August 24, when HY and AHY murrelets become indistinguishable at sea because AHY birds begin pre-basic molt (Long and others, 2001; Peery and others, 2007). Thus, we included only surveys done between July 10 and August 24 to estimate the 2017 juvenile ratio (following Henry, 2017). Identification of HY birds followed techniques outlined by Long and others (2001) and were aided by reviewing photographs and resources provided by the Alaska murrelet group (K. Nesvacil, Alaska Department of Fish and Game, written commun., 2017) before surveys. We included only those birds confidently identified to age class to estimate the juvenile ratio.

We adjusted HY and AHY counts to account for birds estimated to have been inland during the time of the survey. A certain percentage of AHY birds are still incubating young during the fledging period and, therefore, are not on the water during at-sea surveys, potentially creating a positively biased juvenile ratio. The proportion of AHY birds incubating is reported to be less than 6 percent between July 10 and July 17, and less than 1 percent after July 17 (Peery and others, 2004, 2007). Therefore, to correct for the number of AHY birds counted at sea between July 10 and July 17, we calculated, as the date-corrected number of AHY individuals, 


$$
A_{\text {corrected }}=\frac{A_{\text {observed }}}{1-\left(18.7145545-0.18445455 \times D A T E_{i}+0.00045455 \times D A T E_{i}^{2}\right)},
$$

where $A_{\text {observed }}$ is the number of after-hatch-year (AHY) birds counted on survey $i$, and the denominator is 1 minus the linear regression model for the proportion of incubating AHY individuals estimated for the Julian Day of survey $i\left(D A T E_{i}\right.$; Peery and others, 2007). For surveys after Julian Day 199, we assumed no birds were incubating and the observed number of AHY birds was not corrected.

In addition to adjusting for incubating adults (to avoid positive bias in the estimated ratio), the juvenile ratio calculation can be negatively biased by not accounting for HY birds that have not yet fledged by the time of the survey. Based on 47 observed fledging events in California, Peery and others (2007) estimated that 75 percent of juveniles had fledged by August 24, considered herein to be the last day of the fledging period. Therefore, to adjust for the number of HY birds observed during a given at-sea survey, we calculated $H_{\text {corrected }}$ after Peery and others (2007):

$$
H_{\text {corrected }}=\frac{H_{\text {observed }}}{-1.5433+0.0098 \times D A T E_{i}},
$$

where $\quad H_{\text {corrected }}$ is the date-corrected number of hatch-year (HY) individuals, $H_{\text {observed }}$ is the number of HY individuals counted on survey $i$, and the denominator is the regression model for the cumulative proportion of HY birds fledged predicted according to Julian Day $\left(D A T E_{i}\right)$.

We used $A_{\text {corrected }}$ and $H_{\text {corrected }}$ to estimate the juvenile ratio $\left(\hat{R}_{t}\right)$ for year $t$,

$$
\hat{R}_{t}=\frac{\sum_{1}^{n} H_{i}}{\sum_{1}^{n} A_{i}}
$$

where $H_{i}$ and $A_{i}$ are the number of hatch-year and after-hatch-year individuals for survey $i$, respectively, and $n$ is the number of surveys done in year $t$ (Levy and Lemeshow, 1991). We estimated the variance of the juvenile ratio $\left(\operatorname{var}\left(\hat{H}_{t}\right)\right.$ as:

$$
\operatorname{vâr}\left(\hat{R}_{t}\right)=\frac{1}{n}\left(\frac{\operatorname{vâr}\left(\hat{H}_{t}\right)}{\hat{\bar{A}}_{t}^{2}}+\frac{\hat{\bar{H}}_{t}^{2} \operatorname{vâr}\left(\hat{A}_{t}\right)}{\hat{\bar{A}}_{t}^{4}}-\frac{2 \hat{\bar{H}}_{t} \operatorname{côv}\left(\hat{H}_{t}, \hat{A}_{t}\right)}{\hat{\bar{A}}_{t}^{3}}\right)
$$

where

$\operatorname{var}\left(\hat{H}_{t}\right) \quad$ is the variance in the number of hatch-year (HY) individuals observed in year $t$,

$\operatorname{varr}\left(\hat{A}_{t}\right) \quad$ is the variance in the number of after-hatch-year (AHY) individuals observed in year $t$,

$\operatorname{cov}\left(\hat{H}_{t}, \hat{A}_{t}\right) \quad$ is the covariance between the numbers of HY and AHY individuals observed in year $t$, and

$\hat{\bar{H}}_{t}$ and $\hat{\bar{A}}_{t} \quad$ are the mean number of HY and AHY individuals observed in year $t$, respectively (van Kempen and van Vliet, 2000; Peery and others, 2007; Henry, 2017).

We did all calculations to estimate juvenile ratios (uncorrected and corrected) and associated variance using custom scripts provided by M.Z. Perry (University of Wisconsin-Madison, written commun., October 26, 2017) and run with SAS/STAT ${ }^{\circledR}$ software (SAS, Cary, North Carolina). 


\section{Marbled Murrelet Abundance and Productivity Results}

\section{Abundance Estimation Results}

We detected 198 marbled murrelet groups consisting of 336 individuals on all surveys combined in 2017. Detections approached zero at $120 \mathrm{~m}$; therefore, consistent with Henry (2017), we excluded from analysis observations greater than $120 \mathrm{~m}$ from the transect line. We included flying birds (11 percent of all detections less than or equal to $120 \mathrm{~m}$ from the transect line; following Henry [2017]). After removing eight detections greater than $120 \mathrm{~m}$ and one detection with no specified distance, we estimated marbled murrelet abundance using 189 detections of 321 individuals (table 2, fig. 1).

For all surveys combined (regardless of draw direction), the half-normal detection model with no monotonicity constraints (that is, no cosine adjustments) was the bestfitting model, and the observed number of sightings were not significantly different from the number predicted using this detection model (chi-squared $\left[\chi^{2}\right]=2.24$, degrees of freedom $[\mathrm{df}]=4$, probability value $[P]=0.69$; fig. 2 ). Surveyspecific marbled murrelet density estimates ranged from 1.74 to 7.18 birds $\mathrm{km}^{-2}$ in the nearshore stratum and from 0.00 to 3.85 birds $\mathrm{km}^{2}$ in the offshore stratum; survey-specific abundance estimates ranged from 199 to 961 individuals (table 2). The abundance estimated for the entire study area using all surveys was 530 birds (95-percent CI, 384-732 birds; percent coefficient of variation [CV], 15.46; table 3 ). The half-normal detection model with no monotonicity constraints was the best-fitting model for north drawn surveys $\left(\chi^{2}=1.06\right.$, $\mathrm{df}=4, P=0.90)$. The half-normal detection model with a cosine (order 2) adjustment was the best-fitting model for south-drawn surveys $\left(\chi^{2}=0.71, \mathrm{df}=3, P=0.87\right)$. Estimated abundance for surveys drawn from the north (413 birds; 95-percent CI, 247-689 birds) was less than for surveys drawn from the south (790 birds; 95-percent CI, 487-1,280 birds; table 3). Estimated abundances for all study years (19992017) are shown in table 3 and figure 3. Estimated abundances from 2017 are comparable to most prior years of study, except for 2008 and 2015, which had anomalously low abundances (table 3, fig. 3).

\section{Productivity—Juvenile Ratio Results}

We detected three HY marbled murrelets in 2017, one on July 12, and two on August 18 (table 2, fig. 1). In 2017, the uncorrected juvenile ratio $(R)$ was $=0.012 \pm 0.007$ standard error [SE] and the corrected juvenile ratio $(\hat{R})$ was 0.022 $\pm 0.014 \mathrm{SE}$ (table 4). Estimated uncorrected and corrected juvenile ratios for all study years (1996-2017) are shown in table 4 and figure 4. Historical (pre-2017) juvenile ratio values presented in table 4 and figure 4 were obtained using various survey transect designs. Surveys used for juvenile estimates followed (1) shore-parallel transects near Año Nuevo for 1996-98, (2) standardized zigzag transects for 2001-17 (a subset of the abundance estimation transects), or (3) a combination of shore-parallel Año Nuevo transects and standardized zigzag transects for 1999-2000. We present historical values here as calculated and reported by Henry (2017), but do not compare values across years.

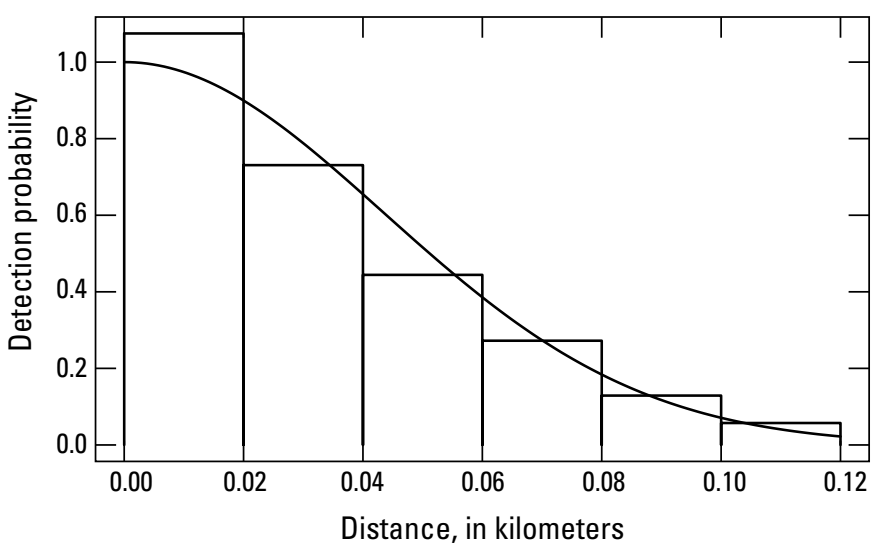

Figure 2. Modeled detection probability of marbled murrelets (Brachyramphus marmoratus) sighted within perpendicular distance less than or equal to 120 meters of vessel for all surveys, Conservation Zone 6, central California, 2017. Bin width is 20 meters. 


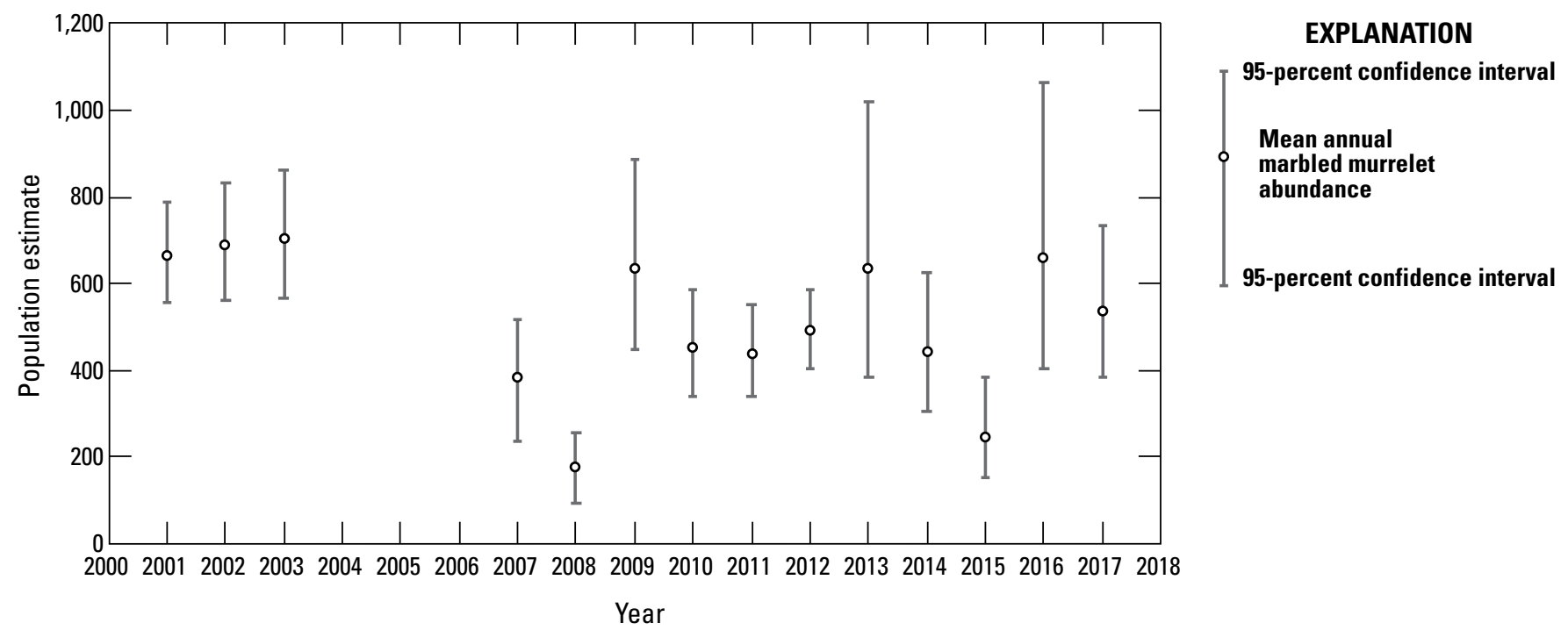

Figure 3. Mean annual marbled murrelet (Brachyramphus marmoratus) at-sea abundance estimates, Conservation Zone 6, central California, for all years for which survey data were available during 2001-17. Years 1999 and 2000 are excluded because survey routes were only drawn from the north in those years.

Table 3. Annual at-sea marbled murrelet (Brachyramphus marmoratus) estimates for surveys drawn in both directions, surveys only drawn from the north, and surveys only drawn from the south, Conservation Zone 6, central California, $1999-2017$.

[All values from years prior to 2017 were referenced from Henry (2017). N: At-sea abundance estimate. 95\% CI: 95-percent confidence interval of the abundance estimate. $\boldsymbol{n}$ : Number of surveys used in the abundance estimate]

\begin{tabular}{|c|c|c|c|c|c|c|c|c|c|}
\hline \multirow{2}{*}{ Year } & \multicolumn{3}{|c|}{ Both directions } & \multicolumn{3}{|c|}{ North } & \multicolumn{3}{|c|}{ South } \\
\hline & $N$ & $95 \% \mathrm{Cl}$ & $n$ & $N$ & $95 \% \mathrm{Cl}$ & $n$ & $N$ & $95 \% \mathrm{Cl}$ & $n$ \\
\hline 1999 & & N/A & & 487 & $333-713$ & 5 & & No surveys & \\
\hline 2000 & & N/A & & 496 & $338-728$ & 8 & & No surveys & \\
\hline 2001 & 661 & $556-786$ & 15 & 637 & $441-920$ & 8 & 733 & $583-922$ & 7 \\
\hline 2002 & 683 & $561-832$ & 15 & 628 & $487-809$ & 9 & 729 & $494-1,075$ & 6 \\
\hline 2003 & 699 & $567-860$ & 12 & 615 & $463-815$ & 6 & 782 & $570-1,074$ & 6 \\
\hline 2004 & & No surveys & & & No surveys & & & No surveys & \\
\hline 2005 & & No surveys & & & No surveys & & & No surveys & \\
\hline 2006 & & No surveys & & & No surveys & & & No surveys & \\
\hline 2007 & 378 & $238-518$ & 4 & 269 & $109-429$ & 2 & 488 & $349-626$ & 2 \\
\hline 2008 & 174 & $91-256$ & 4 & 122 & $61-184$ & 1 & 225 & $131-319$ & 3 \\
\hline 2009 & 631 & $449-885$ & 8 & 495 & $232-1,054$ & 4 & 789 & $522-1,193$ & 4 \\
\hline 2010 & 446 & $340-585$ & 7 & 366 & $240-559$ & 4 & 560 & $343-925$ & 3 \\
\hline 2011 & 433 & $339-553$ & 6 & 320 & $225-454$ & 2 & 452 & $331-618$ & 4 \\
\hline 2012 & 487 & $403-588$ & 6 & 475 & $373-605$ & 3 & 501 & 359-699 & 3 \\
\hline 2013 & 628 & $386-1,022$ & 6 & 439 & $233-827$ & 3 & 556 & $126-2,456$ & 3 \\
\hline 2014 & 438 & $307-624$ & 9 & 444 & $258-765$ & 4 & 434 & $231-817$ & 4 \\
\hline 2015 & 243 & $152-386$ & 9 & 225 & $136-370$ & 4 & 296 & $159-549$ & 5 \\
\hline 2016 & 657 & $406-1,063$ & 7 & 510 & $358-726$ & 3 & 720 & $297-1,747$ & 4 \\
\hline 2017 & 530 & $384-732$ & 9 & 413 & $247-689$ & 4 & 790 & $487-1,280$ & 5 \\
\hline
\end{tabular}




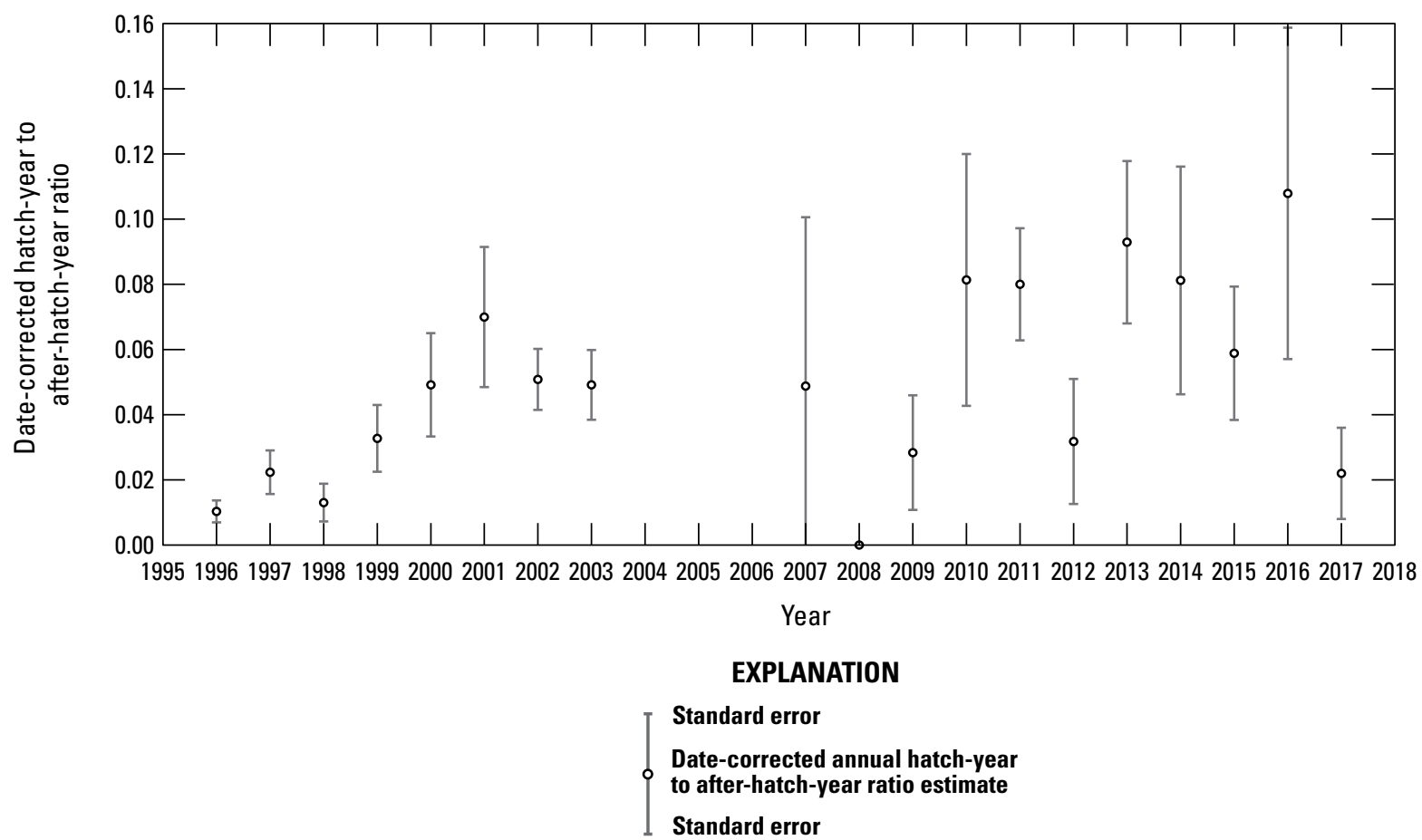

Figure 4. Date-corrected marbled murrelet (Brachyramphus marmoratus) hatch-year to after-hatch-year ratios, plus or minus standard errors, Conservation Zone 6, central California, for all years for which survey data was available during 1996-2017. All values from years prior to 2017 were referenced from Henry (2017). Surveys used to estimate ratios were limited to July 10-August 24. Datecorrected estimates were corrected for the proportion of hatch-year murrelets that had not fledged and the proportion of after-hatchyear murrelets still incubating at the time the survey was done (see Peery and others, 2007).

Table 4. Annual estimates of hatch-year to after-hatch-year ratios $(R)$, date-corrected ratios $(\hat{R})$, and standard errors (SE) for marbled murrelets (Brachyramphus marmoratus) from at-sea surveys done during the breeding season, Conservation Zone 6, central California, 1996-2003 and 2007-17.

[All values from years prior to 2017 were referenced from Henry (2017). Surveys used to estimate ratios were limited to July 10-August 24 . Corrected estimates were corrected for the proportion of hatch-year murrelets that had not fledged and the proportion of after-hatch-year murrelets still incubating at the time the survey was done (see Peery and others, 2007). $N_{\text {surveys }}$ : Number of surveys used to produce the estimate. Abbreviation: NA, not available]

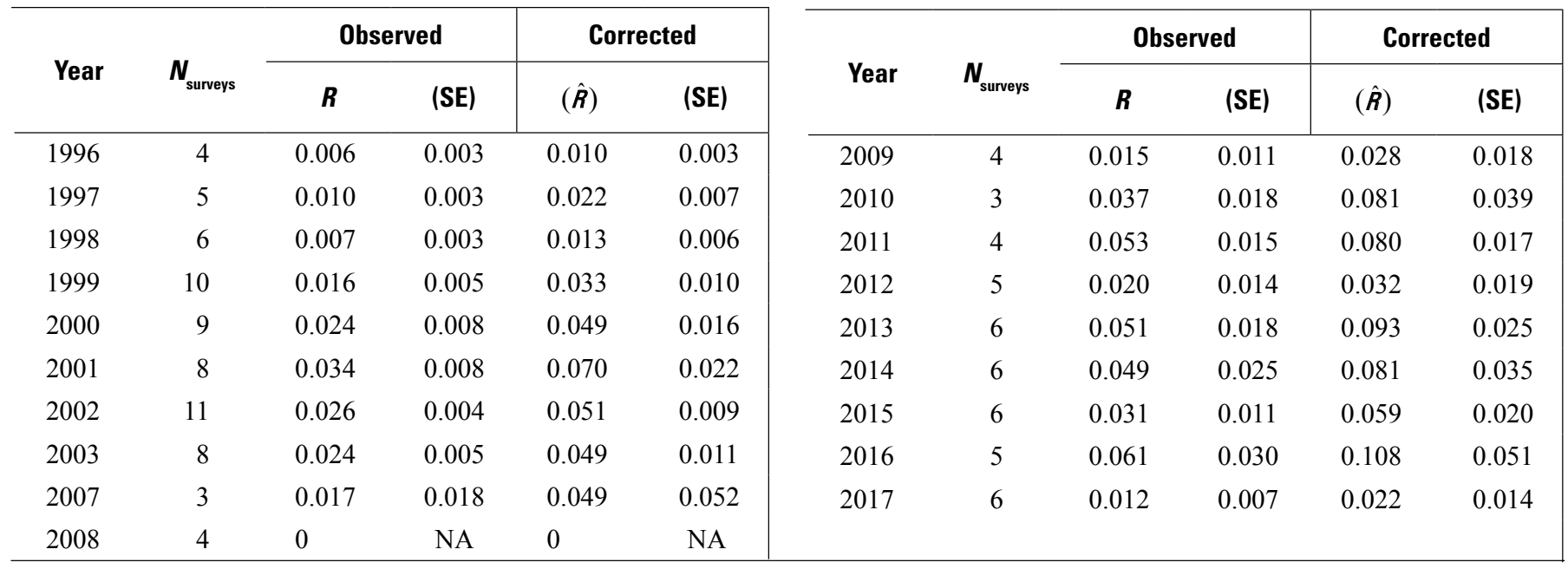




\section{Discussion}

We followed survey methods and analytical procedures to estimate densities and abundances for marbled murrelets using conventional distance sampling off central California according to methods described in Henry (2017). Options for estimating density and abundance using the program DISTANCE v7.1 (Thomas and others, 2010) are flexible, and if adjusted, can yield different density and abundance estimations. Parameters in DISTANCE v.7.1 that can be adjusted include modifying the distribution of perpendicular distances by binning and truncation, the selection of detection functions fit to this distribution, techniques for determining the group-size estimator, and post-stratification. We maintained the previous decision to use a binned distribution ( 20 -m bins) truncated at $120 \mathrm{~m}$ and AIC to select the most parsimonious half-normal detection function for estimation. The current survey design (zigzag lines drawn from the north or south) attempts to accommodate variance in the relative densities of marbled murrelets with respect to distance from shore using inshore (200-1,350 m) and offshore (1,350-2,500 m) strata. This stratification scheme places only about 75 percent of the survey effort in the strata where greater than 90 percent of marbled murrelets are estimated to occur (Becker and others, 1997). The method used from 1999 to 2017 for estimating densities uses these delineations to post-stratify the survey results for analysis in DISTANCE. Variances in density estimates for the offshore strata likely are inflated because of the relatively few, yet variable, detections of marbled murrelets in this zone.

The use of an approximately equal number of transects per year, drawn either from the north $(n=4)$ or south $(n=5)$, attempts to accommodate for the non-random distribution of marbled murrelet aggregation areas associated with variability in the shape of the coastline. Despite survey-specific density estimates (summed nearshore and offshore) and an annual estimate based on the annual pooled detections, the sets of north-drawn and south-drawn surveys traditionally have been evaluated separately using independent detection functions generated respectively from those surveys. Because surveys are always done from north to south, there is no reason to assume and apply different detection functions to estimate density for these two sets. A key concept in distance sampling is "pooling robustness" (Burnham and others, 2004). Pooling robustness, or applying a global detection function based on all sightings to estimate probability of detection, is appropriate in this study because we recognize no specific covariates that could affect detection differently in either nearshore or offshore strata, nor between the north- compared to southdrawn route directions. Although detection functions for north-drawn and south-drawn routes potentially have good fit, variations in the shape and functional response of the detection curves will generate different estimates. For example, using the global detection function, and adhering to the concept of pooling robustness, the average abundance for the five southdrawn surveys in table 2 is 592 murrelets, compared with
790 birds (95-percent CI, 487-1,280 birds) when stratified by survey route direction. A similar comparison for northdrawn surveys is less different (441 compared to 413 birds; 95-percent CI, 247-689 birds).

If the objective for annual assessments of marbled murrelet abundance is to determine trends through time, then the focus should be on determining density at sea with the greatest possible degree of precision (that is, minimal variance). Because the distribution of murrelets off central California tends to be patchy and non-randomly distributed between Half Moon Bay and Santa Cruz, revised density estimates could be achieved using alternate post-stratification strategies. In addition to considering different distance breaks to delineate nearshore/offshore strata, more than 1 decade of surveys has shown that although few murrelets have been sighted south of Davenport, this area was allocated about 25 percent of the total survey effort. By contrast, the area near Point Año Nuevo consistently supports the greatest number of sightings. Along-shore post-stratification may result in density estimates with tighter confidence intervals (that is, less variance), which would allow for better resolution (that is, greater power) to detect inter-annual trends.

Becker and others (1997) presented a review of several studies, as well as an informative comparison of strip and line-transect methods used to measure the densities of marbled murrelets at sea. In their analyses, the authors compared the means and standard deviations as well as the power to detect trends in at-sea densities among 100-m strips, 200-m strips, and line transects placed at variable distances from the coast. Based on Becker and others (1997), scientists adopted the current zigzag survey design in 1999. Almost two decades later, we are not aware of any attempt to refine analyses and examine the power to detect change through time in marbled murrelet density at sea using this adopted survey design in Conservation Zone 6. A substantial time-series of marbled murrelet surveys is now available (Felis and others, 2018) that warrants a comprehensive evaluation of survey biases, distribution at sea, and sampling design. Additionally, new opportunities for more contemporary analysis beyond conventional distance sampling could be examined (for example, revised post-stratification, multiple covariate distance sampling, and density surface modeling; Buckland and others, 2015).

Although methods and protocols have largely remained the same, the annual marbled murrelet survey program has been carried out by several different entities through time and, until now, there has been no secure, fully documented database available. We created a synthesized database of all marbled murrelet survey data from 1999 to 2017 to allow scientists and managers to evaluate established survey methods and assess trends in abundance estimation and juvenile ratios (Felis and others, 2018). This database also facilitates annual survey logistics (for example, pre-survey planning) as well as repeatability of analytical methods across years and project teams. 


\section{Summary}

We estimated at-sea abundance and productivity of marbled murrelets (Brachyramphus marmoratus) in U.S. Fish and Wildlife Service Conservation Zone 6 (central California-San Francisco Bay to Monterey Bay) in 2017 using vessel-based surveys and conventional distance sampling methods. The abundance estimated for the study area was 530 birds (95-percent confidence interval, 384-732 birds). Estimated abundance from 2017 is comparable to most prior years of study, except for 2008 and 2015, which had anomalously low abundances. Estimated productivity (calculated as a date-corrected hatch-year [HY] to afterhatch-year [AHY] ratio) in 2017 was $0.022 \pm 0.014$ standard error. We created a synthesized database of all marbled murrelet survey data from 1999 to 2017 to allow scientists and managers to evaluate established survey methods and assess trends in abundance and productivity estimates.

\section{Acknowledgments}

We would like to thank our additional murrelet observers Max Czapanskiy (U.S. Geological Survey [USGS], University of California at Santa Cruz [UCSC]) and Alex Rinkert. Dave Benet and the UCSC small boat program provided excellent vessel support and maintained the $R / V$ Lucy $M$. Portia Halbert (California State Parks) provided support and insight and assisted with transitioning the survey program from Bill Henry (Groundswell Coastal Ecology) to the USGS. Thanks to Bill for his patience and contributions. M. Zach Peery (University of Wisconsin-Madison) kindly provided data and SAS code to calculate juvenile ratios and associated variance. Julie Yee (USGS) kindly ran Zach's code. We would especially like to thank our talented additional vessel operators and truck drivers: Jessie Beck, Kate Vylet (UCSC), Cordell Johnson (USGS), Jackson Currie (USGS), Spencer Gordon (California State Parks), and Dave Cowman (California State Parks).

\section{References Cited}

Becker, B.H., Beissinger, S.R., and Carter, H.R., 1997, At-sea density monitoring of marbled murrelets in central California-Methodological considerations: The Condor, v. 99, no. 3, p. 743-755, https://doi.org/10.2307/1370485.

Buckland, S.T., Rexstad, E.A., Marques, T.A., and Oedekoven, C.S., 2015, Distance sampling-Methods and applications: Cham, Switzerland, Springer International Publishing, 277 p., https://doi.org/10.1007/978-3-319-19219-2.
Burnham, K.P., and Anderson, D.R., 2004, Multimodel inference-Understanding AIC and BIC in model selection: Sociological Methods and Research, v. 33, no. 2, p. 261-304.

Burnham, K.P., Buckland, S.T., Laake, J.L., Borchers, D.L., Marques, T.A., Bishop, J.R.B., and Thomas, L., 2004, Further topics in distance sampling, in Buckland, S.T., Anderson, D.R., Burnham, K.P., Laake, J.L., Borchers, D.L., and Thomas, L., eds., Advanced distance sampling: Oxford, United Kingdom, Oxford University Press, p. 307-392.

California Department of Fish and Wildlife, 2004, Generalized California coastline - coastn83.shp: California Department of Fish and Wildlife database, accessed October 20, 2017, at https://www.wildlife.ca.gov/Conservation/Marine/GIS/ Downloads.

Felis, J.J., Adams, J., Peery, M.Z., Henry, R.W., Henkel, L.A., Becker, B.H., and Halbert, P., 2018, Annual marbled murrelet abundance and productivity surveys off central California (Zone 6), 1999-2017: U.S. Geological Survey data release, https://doi.org/10.5066/F75B01RW.

Henkel, L.A., 2004, At-sea distribution of marbled murrelets in San Luis Obispo County, California: Watsonville, California, H.T. Harvey and Associates, 14 p.

Henkel, L.A., and Peery, M.Z., 2008, Abundance and productivity of marbled murrelets off central California during the 2007 breeding season: Moss Landing, California, Moss Landing Marine Laboratories, 13 p.

Henry, R.W., 2017, Murrelet at-sea abundance, productivity, and prey resources in Zone 6, in Halbert, P. and Singer, S.W., eds., Marbled murrelet landscape management plan for zone 6, Felton, California: California Department of Parks and Recreation, $235 \mathrm{p}$.

Henry, R.W., Tyler, W.B., and Peery, M.Z., 2012, Abundance and productivity of marbled murrelets off central California during the 2010 and 2011 breeding seasons: Half Moon Bay, California, California State Parks, 17 p.

Levy, P.S., and Lemeshow, S., 1991, Sampling of populations - Methods and applications ( $2 \mathrm{~d}$ ed.): New York, Wiley, $420 \mathrm{p}$.

Long, L.L., Ralph, C.J., and Miller, S.L., 2001, A new method for ageing marbled murrelets and the effect on productivity estimates: Pacific Seabirds, v. 28, p. 82-91.

Peery, M.Z., Becker, B.H., and Beissinger, S.R., 2006, Combining demographic and count-based approaches to identify source-sink dynamics of a threatened seabird: Ecological Applications, v. 16, no. 4, p. 1516-1528, https:// doi.org/10.1890/1051-0761(2006)016[1516:CDACAT]2.0 .CO;2. 


\section{Abundance and Productivity of Marbled Murrelets Off Central California during the 2017 Breeding Season}

Peery, M.Z., Becker, B.H., and Beissinger, S.R., 2007, Age ratios as estimators of productivity-Testing assumptions on a threatened seabird, the marbled murrelet: The Auk, v. 124 , no. 1 , p. 224-240, https://doi.org/10.1642/00048038(2007)124[224:ARAEOP]2.0.CO;2.

Peery, M.Z., Beissinger, S.R., Newman, S.H., Burkett, E.B., and Williams, T.D., 2004, Applying the declining population paradigm-Diagnosing causes of poor reproduction in the marbled murrelet: Conservation Biology, v. 18, no. 4, p. 1088-1098, https://doi.org/10.1111/j.15231739.2004.00134.x.

Peery, M.Z., and Henry, R.W., 2010, Abundance and productivity of marbled murrelets off central California during the 2009 breeding season: Half Moon Bay, California, California State Parks, 16 p.

Peery, M.Z., Newman, S.H., Storlazzi, C.D., and Beissinger, S.R., 2009, Meeting reproductive demands in a dynamic upwelling system-Foraging strategies of a pursuit-diving seabird, the marbled murrelet: The Condor, v. 111, no. 1, p. 120-134, https://doi.org/10.1525/ cond.2009.080094.

Ralph, C.J., and Miller, S.L., 1995, Offshore population estimates of marbled murrelets in California, in Ralph, C.J., Hunt, G.L., Raphael, M.G., and Piatt, J.F., eds., Ecology and conservation of the marbled murrelet: U.S. Forest Service General Technical Report PSW-GTR-152 p. 353-360.
R Core Team, 2016, R-A language and environment for statistical computing: Vienna, Austria, R Foundation for Statistical Computing, https://www.R-project.org/.

Strong, C.S., Keitt, B.S., Bradford, S., McIver, W.R., Palmer, C.J., and Gaffney, I., 1995, Distribution and population estimates of marbled murrelets at sea in Oregon during the summers of 1992 and 1993, in Ralph, C.J., Hunt, G.L., Jr., Raphael, M.G., and Piatt, J.F., eds., Ecology and conservation of the marbled murrelet: U.S. Forest Service General Technical Report PSW-GTR-152, p. 339-352.

Thomas, L., Buckland, S.T., Rexstad, E.A., Laake, J.L., Strindberg, S., Hedley, S.L., Bishop, J.R.B., Marques, T.A., and Burnham, K.P., 2010, Distance software-Design and analysis of distance sampling surveys for estimating population size: Journal of Applied Ecology, v. 47, no. 1, p. 5-14, https://doi.org/10.1111/j.1365-2664.2009.01737.x.

van Kempen, G.M.P., and van Vliet, L.J., 2000, Mean and variance of ratio estimators used in fluorescence imaging: Cytometry, v. 39, no. 4, p. 300-305, https://doi. org/10.1002/(SICI)1097-0320(20000401)39:4<300::AIDCYTO8>3.0.CO;2-O. 
Publishing support provided by the U.S. Geological Survey Science Publishing Network, Tacoma Publishing Service Center

For more information concerning the research in this report, contact the Director, Western Ecological Research Center

U.S. Geological Survey

3020 State University Drive

Modoc Hall, Room 4004

Sacramento, California 95819

https://www.werc.usgs.gov/ 
뭄

흘

官

을

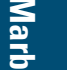

용

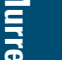

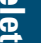

울

禺

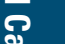

흘

을.

宫

(2)

금

喭

을

를

居

밍

ज्ञ

悉.

居 